\title{
Leaf damage in a mangrove swamp at Sepetiba Bay, Rio de Janeiro, Brazil
}

\author{
LUIS FERNANDO TAVARES DE MENEZES ${ }^{1,3}$ and ARIANE LUNA PEIXOTO²
}

(received: July 4, 2007; accepted: August 19, 2009)

\begin{abstract}
Leaf damage in a mangrove swamp at Sepetiba Bay, Rio de Janeiro, Brazil). Leaf damage to Rhizophora mangle L., Avicennia schaueriana Stapf. \& Leechman, and Laguncularia racemosa L. was studied in a two hectare mangrove swamp site in Sepetiba Bay. Seventeen arthropod morphospecies were identified as being responsible for the damage, and their species diversity was highest on A. schaueriana, followed by $R$. mangle and L. racemosa. Damage in terms of relative area was greatest in L. racemosa. Almost 9\% of mangrove canopy leaf area demonstrated some damage. Loss of leaf area to herbivory was $12.1 \%, 8.3 \%$ and $6.2 \%$ in $L$. racemosa, A. schaueriana and $R$. mangle respectively. L. racemosa and A. schaueriana showed high percentages of leaf-margin damage in terms of the total damaged leaf area (82.2\% and 56.3\% respectively), while the most important type of damage in $R$. mangle was necrosis, representing $58.1 \%$ of the total damaged leaf area.
\end{abstract}

Key words - Avicennia schaueriana, herbivory, Laguncularia racemosa, mangrove, Rhizophora mangle

RESUMO - (Danos foliares em um mangue na Baía de Sepetiba, Rio de Janeiro, Brasil). Um trecho com 2 ha de mangue na Baía de Sepetiba foi estudado quanto ao dano foliar em Rhizophora mangle L., Avicennia schaueriana Stapf. \& Leechman. e Laguncularia racemosa L. Foram reconhecidas 17 morfospécies de artrópodes causadoras de dano. A. schaueriana apresentou maior riqueza de morfoespécies danificadoras de folhas, seguida de $R$. mangle e L. racemosa. A area relativa de dano foi maior em $L$. racemosa e menor em $R$. mangle. Nossos resultados mostraram que 8,8\% da área foliar do dossel do mangue estudado foi afetado pela predação. A perda de área foliar por herbivoria foi de $12,1 \%, 8,3 \%$ e 6,2\% em $L$. racemosa, A. schaueriana and $R$. mangle, respectivamente. O consumo da borda da folha foi mais expressivo em L. racemosa and A. schaueriana, correspondendo a $82,2 \%$ and $56,3 \%$ de dano total na folha, respectivamente. Em $R$. mangle, o dano mais expressivo foi a necrose que correspondeu a 58,1\% de toda a área de dano foliar.

Palavras-chave - Avicennia schaueriana, herbivoria, Laguncularia racemosa, mangrove, Rhizophora mangle

\section{Introduction}

Mangrove forests serve as organic debris sources for coastal food chains, principally from their senescent leaves (Lugo \& Snedaker 1974, Odum \& Heald 1975, Boto \& Bunt 1982). This organic production can vary between 1 and $10 \mathrm{t} \mathrm{ha}^{-1}$ year $^{-1}$, making mangrove swamps one of the principal factors responsible for the high fishery productivity of tropical waters (D’Croz \& Kwiecinski 1980, IUCN 1983, Lacerda \& Rezende 1990).

In spite of the pantropical distribution and importance of mangrove swamps the entomofauna associated with these environments is still only poorly known. The activities of leaf-consumer organisms have been examined in only a few localities in the world, and generally only moderate damage has been reported (not exceeding $50 \%$ of the leaf area) (Erickson et al. 2004,

1. Centro Universitário Norte do Espírito Santo / UFES, Depto. de Ciências Agrárias e Biológicas, BR 101 Norte, km 60, Bairro Litorâneo, São Mateus, 29932-540 Espírito Santo, Brazil.

2. Instituto de Pesquisa Jardim Botânico do Rio de Janeiro, Rua Pacheco Leão, 915, Jardim Botânico, 22460-030 Rio de Janeiro, RJ, Brazil.

3._Corresponding author: ltmenezes@gmail.com
Offenberg et al. 2004). Leaves of mangrove swamp plants are, in fact, considered to show relatively little damage because they are heavily protected by tannin compounds and other efficient inhibitors of insect herbivores (Huffaker et al. 1984, Hernes et al. 2001, Skov \& Hartnoll 2002). Nonetheless, the literature also contains reports of severe leaf-loss events in some species found in mangrove swamps (Lee 1991, Anderson \& Lee 1995, Elster et al. 1999, Menezes \& Mehlig 2005).

Studies of leaf damage caused by insect herbivores generally refer to the quantification of the missing area leaf in relation to the potential (full) leaf area (Johnstone 1981, Lacerda et al. 1986, Dirzo 1987, Marquis 1987, Ellison \& Farnsworth 1996) and have not taken into consideration many types of damage that do not necessarily cause a loss of the leaf area, such as necrosis, boring, galls and scraping (although these likewise signify the loss of photosynthetically active areas). Leaf damage in mangrove swamp plants can compromise the productivity of those environments (Lacerda et al. 1986) through the direct loss of photosynthetic area, reallocation of plant metabolic resources to herbivore defenses (Coley et al. 1985, Ernest 1989, Gange \& 
Brown 1989) or, in extreme cases, the death of large numbers of a given species (West \& Thorogood 1985, Whitten \& Damanik 1986, Murphy 1990, Farnsworth \& Ellison 1991, Anderson \& Lee 1995). Additionally, herbivory can interfere with the developmental and/or reproductive patterns of the plants (Gange \& Brown 1989, Gonçalves-Alvim et al. 2001) and seedling recruitment, and alter forest structures (McKee 1995, Farnsworth \& Ellison 1997). In spite of the importance of these topics to mangrove ecology, few studies in these ecosystems have classified leaf damage or investigated their causal agents (Onuf et al. 1977, Farnsworth \& Ellison 1991, Anderson \& Lee 1995, McKee 1995, Stowe 1995).

The comparatively simple structure of a mangrove community allowed us to investigate the following questions: i) do the types of damage and total amount of leaf damage encountered in mangrove forest trees vary in terms of the different species? and, ii) does the amount of damaged leaf area demonstrate seasonal variations? The present study therefore sought to classify and compare the different types of leaf damage encountered in Rhizophora mangle L., Avicennia schaueriana Stapf. \& Leechman., and Laguncularia racemosa L. and identify the causative agents of this damage in a mangrove forest in Sepetiba Bay, Rio de Janeiro State, Brazil.

\section{Material and methods}

Study area - The present study was undertaken during the period between May 1991 and April 1992 in an area of two hectares in a mangrove swamp located on the right bank of the mouth of the Piraquê River as it flows into Sepetiba Bay along the southern border of the Guaratiba Biological and

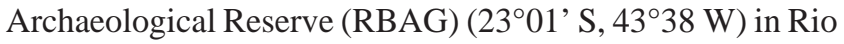
de Janeiro State, Brazil. This bay covers an area of $305 \mathrm{~km}^{2}$ and mangrove swamps are located primarily along its eastern edge (Roncarati \& Barrocas 1978). The mangrove swamps in this region are populated principally by Rhizophora mangle, Laguncularia racemosa, and Avicennia schaueriana (which will be referred to here by their generic names) and these plants are distributed throughout the area without any apparent defined zonation. Hibiscus pernambucensis and Acrostichum aureum can also be found in areas with slightly higher elevations in the mangrove swamp. Two basic vegetation types can be identified in the region: a dominant form with trees reaching up to $5 \mathrm{~m}$ tall that extends through the entire forest; and a second form that is well represented in the rivers and tidal canals and is dominated by individuals of Rhizophora that can reach $25 \mathrm{~m}$ in height, with trunks measuring up to $50 \mathrm{~cm}$ of diameter at breast height. In other regions of the RBAG mangrove swamp that are located further from the canals, Rhizophora dominates in terms of the numbers of trees, but Avicennia is represented by much larger individuals. The species Laguncularia is less common, and almost always associated with Rhizophora and Avicennia. This latter taxon has the widest distribution, occupying areas that are both saltier and more elevated (Dias-Brito \& Zaninetti 1979).

Climate - The study area macroclimate is classified as Aw (Tropical Rainy) according to the Köppen system, with air temperatures typical of tropical coastal zones. The average annual temperature is $23.7^{\circ} \mathrm{C}$, with February being the warmest month (average $26.9^{\circ} \mathrm{C}$ ) while August is the coldest (average $20.9^{\circ} \mathrm{C}$ ). The average annual rainfall is $1237.7 \mathrm{~mm}$, with $37 \%$ occurring during the summer and condensed into about 40 rainy days. The winter months are drier, accounting for only $15 \%$ of the average annual rainfall, which is distributed in about 21 days. The average monthly rainfall during July and August is between 40 and $55 \mathrm{~mm}$, although in dry years it can drop to less than $30 \mathrm{~mm}$, corresponding to an accentuated drought for the region (Mattos 2005). The climatic data utilized here was furnished by the Instituto Nacional de Meteorologia (INMET) based on information from the Marambaia meteorological station $\left(23^{\circ} 03^{\prime} \mathrm{S}, 43^{\circ} 36^{\prime} \mathrm{W}\right)$ located approximately $7 \mathrm{~km}$ from the study area.

Sampling strategies - At monthly intervals during the study period ten adult individuals of Avicennia, Laguncularia, and Rhizophora having diameters at breast height $(\mathrm{DBH})>2.5 \mathrm{~cm}$ were chosen at random and five leaves were collected from each plant. The individuals sampled were then marked so that they would not be sampled again in the following months. As herbivore damage is not distributed uniformly in the plant crown and can vary greatly among different branches and leaves or according to the age of the plant (Coley 1980, 1983, Lowman 1985, Ernest 1989, Basset 1991, Coley \& Aide 1991, Loyola Jr. \& Fernandes 1993, Nascimento \& Hay 1993), the sampling was standardized to collect only the third pair of leaves on randomly chosen branches (Filomeno \& Castellani 1990). In order to collect the highest branches an extendable pruning pole was used (with a $15 \mathrm{~m}$ reach).

Leaf damage was classified as follows: damage caused by gall-forming arthropods were denominated "galls"; predation on the leaf margins was denominated "leafmargin" damage; rasping of the leaf cuticle (on either the dorsal or ventral face of the leaf) was denominated "rasping"; predation part of the leaf blade without damaging the leaf margin was denominated a "hole"; necrosis of the leaf tissue was generically denominated "necrosis"; spots not larger than $1 \mathrm{~mm}^{2}$ that were infested by fungi were denominated "fungal spots"; and predation of the leaf mesophyll while maintaining the integrity of the cuticle was denominated "leaf-mining". Damage that did not fit perfectly into any of these classes and that had not been caused by herbivores (as, for example, deformities caused by mechanical stress) was denominated "undefined damage".

The complete area of each leaf was obtained by drawing its outline on a piece of paper, and in the case of 
leaves with damaged borders, their presumed original shapes were completed by drawing dotted lines. These drawings were subsequently cut out with a scissors and their areas quantified using a Li-Cor model Li - 3.100 Area Meter (Beerling \& Fry 1990). The outline of each type of damage visible on each leaf was also outlined on paper, cut out, and subsequently quantified using the Area Meter apparatus (with the exception of the fungal dots). The areas of the fungal spots were standardized at $1 \mathrm{~mm}^{2}$ each (this value was never exceeded) and the total density of these points corresponded to the damaged area.

In parallel with the collection of the leaf samples, any invertebrates observed consuming the leaves were also collected. Any lepidopteron larvae found were taken to the laboratory (and maintained on the same leaves they were observed consuming in the field) and allowed to metamorph into adults for identification. The herbivores and pathogens responsible for leaf damage were identified by specialists at the Entomology Department of the National Museum - Federal University of Rio de Janeiro and in the Phytopathology Department of Federal Rural University of Rio de Janeiro. All entomological material collected during the course of the field work was deposited in the Ângelo Moreira da Costa Lima Collection of the Federal Rural University of Rio de Janeiro.

In performing the statistical analysis, the homogeneity of the variance and the normality of the frequency distributions of the data were verified using the Cochran \& Bartlett and Lilliefors tests respectively. Variables that did not satisfactorily approximate normality or homogeneity were mathematically transformed (as indicated in the tables and figures). Variance analysis was used to compare averages, followed by the Tukey test at 5\% (Zar 1999). All analyses were performed using the SAEG statistical software package of the Arthur Bernardes Foundation.

Any given type of damage was considered to be present if it was observed on the leaf, independent of its extent or density.

\section{Results and discussion}

Climate - December was the warmest month during the study period $\left(26.3^{\circ} \mathrm{C}\right)$ and September the coldest $\left(17.8^{\circ} \mathrm{C}\right.$ ) (figure 1$)$. Rainfall was greatest during the month of January (322.4 mm) and least during April $(15.5 \mathrm{~mm})$. The study period was marked by three dry periods: during months of June and August; the month of November; and from February to April. The period from November through February was marked by high rainfall levels.

Types of damage and their causative agents - Eight types of damage were recognized as affecting the mangrove tree leaves (table 1). The damage we encountered was

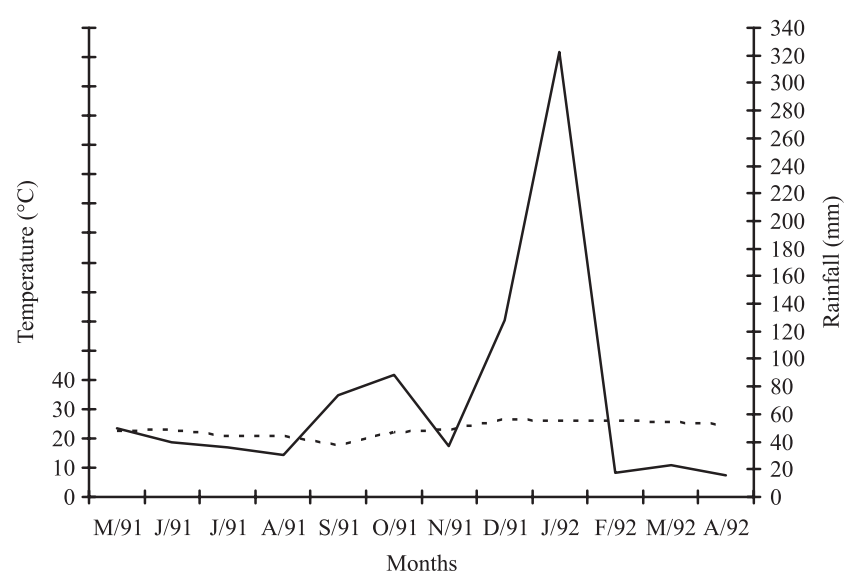

Figure 1. Gaussen-Bagnouls ombrothermic diagram for an area of mangrove swamp at the mouth of the Piraquê River, Sepetiba Bay, Rio de Janeiro State, Brazil, during the period from May 1991 to April 1992. Climatological data was obtained from the Marambaia Weather Station (Instituto Nacional de Meteorologia) located approximately $5 \mathrm{~km}$ from the study area. (- = Rainfall; --- = Average temperature).

similar to that reported in other mangrove swamps in Brazil, Pakistan, the United States, the Bahamas, Belize, China, as well as other localities around the globe (Johnstone 1981, Schoener 1988, Filomeno \& Castellani 1990, Farnsworth \& Ellison 1991, Lee 1991, Stowe 1995, Gonçalves-Alvim et al. 2001, Erickson et al. 2004, Saifullah \& Mahera 2004). Undefined damage caused by deformities of Rhizophora leaves appeared as corky structures, but without any signs of pathologies resulting from fungal or bacterial infections. An exaggerated growth of trichomes on the adaxial surface of the leaves of Avicennia was sometimes observed, but without the presence of external or internal structures that would suggest a fungal origin.

Seventeen predator morphospecies causing leaf damage (table 1) were recognized, with Avicennia being the taxon with the greatest predator diversity (9 morphospecies). Rhizophora and Laguncularia were observed to have equal numbers (5) of morphospecies responsible for leaf damage.

Adults of four species of lepidopterons were frequently collected on mangrove trees during the study period: Amorbia sp., Olethreutinae (Tortricidae); Motya abseuzalis (Walker, 1859) (Noctuidae); and Spoladea recurvalis (Fabricius, 1775) (Pyralidae), although it was not possible to determine which plant species served as the true food source for their larvae, nor to determine the type of damage caused by these insects. Adult specimens of the coleopterans Eumolpus sp. (Chrysomelidae) and 
Table 1. Types of damage and their respective causal agents encountered on Laguncularia racemosa, Avicennia schaueriana and Rhizophora mangle in a mangrove swamp at the mouth of the Piraquê River, Sepetiba Bay, Rio de Janeiro State, Brazil.

\begin{tabular}{|c|c|c|c|}
\hline Type of damage & Plant damaged & Causal agent & Classification \\
\hline Fungal spots & Laguncularia racemosa & Septoria sp. & Fungi \\
\hline Necrosis & $\begin{array}{l}\text { Avicennia schaueriana } \\
\text { Rhizophora mangle } \\
\text { Laguncularia racemosa }\end{array}$ & $\begin{array}{l}\text { Reduviidae } 1 \\
\text { Reduviidae } 2 \\
\text { Reduviidae } 1\end{array}$ & $\begin{array}{l}\text { Hemiptera (Reduviidae) } \\
\text { Hemiptera (Reduviidae) } \\
\text { Hemiptera (Reduviidae) }\end{array}$ \\
\hline Rasping & $\begin{array}{l}\text { Avicennia schaueriana } \\
\text { Rhizophora mangle } \\
\text { Laguncularia racemosa }\end{array}$ & $\begin{array}{l}\text { Junonia evarete (Cramer, 1775) } \\
\text { Melampus coffeus (Linnaeus, 1758) } \\
\text { Geometridae } 1\end{array}$ & $\begin{array}{l}\text { Lepidoptera (Nymphalidae) } \\
\text { Molusca (Ellobidae) } \\
\text { Lepidoptera (Geometridae) }\end{array}$ \\
\hline Holes & $\begin{array}{l}\text { Avicennia schaueriana } \\
\text { Rhizophora mangle } \\
\text { Laguncularia racemosa }\end{array}$ & $\begin{array}{l}\text { Hyblaea puera (Cramer, 1777) } \\
\text { Geometridae } 2 \\
\text { Oiketicus kirbyi (Guilding, 1827) }\end{array}$ & $\begin{array}{l}\text { Lepidoptera (Hyblaeidae) } \\
\text { Lepidoptera (Geometridae) } \\
\text { Lepidoptera (Psychidae) }\end{array}$ \\
\hline Leaf-mining & $\begin{array}{l}\text { Avicennia schaueriana } \\
\text { Laguncularia racemosa }\end{array}$ & $\begin{array}{l}\text { Lepidoptera } 1 \\
\text { Lepidoptera } 1\end{array}$ & $\begin{array}{l}\text { Lepidoptera } \\
\text { Lepidoptera }\end{array}$ \\
\hline Leaf-margin & Avicennia schaueriana & $\begin{array}{l}\text { Junonia evarete (Cramer, 1775) } \\
\text { Rothildia aurota (Cramer, 1775) } \\
\text { Madoryx oiclus (Cramer, 1779) } \\
\text { Oiketicus kirbyi (Guilding, 1827) } \\
\text { Hyblaea puera (Cramer, 1777) } \\
\text { Aratus pisonii (H. Milne Edwaeds, 1837) } \\
\text { Stilpnochlora marginella (Serville, 1839) }\end{array}$ & $\begin{array}{l}\text { Lepidoptera (Nymphalidae) } \\
\text { Lepidoptera (Saturnidae) } \\
\text { Lepidoptera (Sphingidae) } \\
\text { Lepidoptera (Psychidae) } \\
\text { Lepidoptera (Hyblaeidae) } \\
\text { Crustacea (Grapsidae) } \\
\text { Orthoptera (Tettigoniidae) }\end{array}$ \\
\hline & Laguncularia racemosa & Oiketicus kirbyi (Guilding, 1827) & Lepidoptera (Psychidae) \\
\hline & Rhizophora mangle & $\begin{array}{l}\text { Lymantridae } 1 \\
\text { Geometridae } 2 \\
\text { Aratus pisonii (H. Milne Edwaeds, 1837) }\end{array}$ & $\begin{array}{l}\text { Lepidoptera (Lymantridae) } \\
\text { Lepidoptera (Geometridae) } \\
\text { Crustacea (Grapsidae) }\end{array}$ \\
\hline Galls & Avicennia schaueriana & Cecidomyia avicenniae (Cook, 1909) & Diptera (Cecidomyiidae) \\
\hline Undefined & $\begin{array}{l}\text { Avicennia schaueriana } \\
\text { Rhizophora mangle } \\
\text { Laguncularia racemosa }\end{array}$ & Deformities & Mechanical stress \\
\hline
\end{tabular}

Strogylium sp. (Tenebrionidae) were collected numerous times on the leaves of Laguncularia, although it was not possible to determine if they used that plant as a food source. The greatest densities of herbivore species encountered were among the lepidopterons, as has been reported for other mangrove swamps in Brazil and Hong Kong (Filomeno \& Castellani 1990, Lee 1991).

In the laboratory, the lepidopteron species Junonia evarete (Nymphalidae) and Madoryx oiclus (Sphingidae) restricted their diets to the consumption of Avicennia leaves (table 1). These insects did not accept the substitution of these leaves for those of other species growing in the mangrove swamp, most likely due to the presence of different secondary plant defense compounds (Farnsworth \& Ellison 1991).
Variations in total leaf damage area - significant differences were confirmed (ANOVA: $\mathrm{F}=29.31$; $P=0.0001$ ) between the averages of the total damaged leaf areas among the different species studied (Tukey test $P<0.05$ ) (table 2). As we always consider the proportion of the damage in relation to the leaf size, and not the absolute damaged leaf area, a given type of damage that might cover the same area in each of the three mangrove species studied would still generate distinct proportions in relation to the total area of the different leaves.

Laguncularia demonstrated the greatest percentage of damaged leaf area among the three species examined (12.1\%), although this value was not statistically different from Avicennia (8.3\%) $(P>0.05)$ (table 2). These two species, however, did suffer significantly more 
Table 2. Total leaf area, average total leaf area, total damaged leaf area, and percentage of damaged leaf area in Laguncularia racemosa, Avicennia schaueriana and Rhizophora mangle in a mangrove swamp at the mouth of the Piraquê River, Sepetiba Bay, Rio de Janeiro State, Brazil.

\begin{tabular}{lcccc}
\hline Species & $\begin{array}{c}\text { Total leaf area } \\
\text { in } \mathrm{cm}^{2} \\
(\mathrm{~N}=600)\end{array}$ & $\begin{array}{c}\text { Average total } \\
\text { leaf area in } \mathrm{cm}^{2} \\
(\mathrm{~N}=600)\end{array}$ & $\begin{array}{c}\text { Total damaged } \\
\text { leaf area } \\
\left(\mathrm{cm}^{2}\right)\end{array}$ & $\begin{array}{c}\text { Percentage of } \\
\text { damaged leaf area } \\
\text { (relative area damaged) }\end{array}$ \\
\hline Laguncularia racemosa & $14.931,2$ & $24,9 \mathrm{~b} \pm 3,3$ & $1.808,7$ & $12,1 \%\left(0,076 \mathrm{a}^{*}\right)$ \\
Avicennia schaueriana & $13.592,3$ & $22,7 \mathrm{c} \pm 2,8$ & $1.124,1$ & $8,3 \%\left(0,068 \mathrm{a}^{*}\right)$ \\
Rhizophora mangle & $16.509,4$ & $27,5 \mathrm{a} \pm 3,8$ & $1.025,2$ & $6,2 \%\left(0,053 \mathrm{~b}^{*}\right)$ \\
Total & $45.032,9$ & - & $3.958,0$ & $8,8 \%$ \\
\hline
\end{tabular}

Transformed data: * relative area damaged (arcsine of the square root of the percentage). Averages followed by the same letters in any column do not differ significantly by the Tukey test at $5 \%$.

damage than Rhizophora (6.2\%) $(P<0.05)$. The lower percentage of herbivory seen in Rhizophora is probably related to the physical and chemical defenses of this species (Robertson \& Duke 1987). The leaves of this species are known to be extremely resistant (Robertson \& Duke 1987, Fernandes 1994) and their especially high concentrations of soluble tannins as well as the high proportions of carbon/nitrogen in their leaves seem to render them especially unpalatable (Feeny 1976, Fox \& Macauley 1977, Lowman \& Box 1983, Farnsworth \& Ellison 1991).

Studies in other mangrove swamps in Brazil and the world that quantified leaf area loss due to herbivores demonstrated variable (and even contrasting) levels of predation among the same species studied here. In an earlier examination of two mangrove sites near the present study area, for example, Lacerda et al. (1986) found that Avicennia demonstrated a lower herbivory rate (0.5 and $1.5 \%$ ) than Rhizophora (5.5 and 6.2\%). Laguncularia was found to be the most heavily damaged species in Santa Catarina during both the summer (7.5\%) and winter (20.9\%) months (Filomeno \& Castellani 1990). Herbivory resulted in the loss of $5.7 \%$ of the leaf area Laguncularia (Stowe 1995) in the Caribbean region, while in Belize this rate varied from 4.3 to 25.3\% in Rhizophora (Farnsworth \& Ellison 1991). Even higher values for these and other species have reported in the mangrove swamps of Florida and tended to oscillate between $26 \%$ and $47 \%$ of the total area of the leaf (Onuf et al. 1977, Erickson et al. 2004). The variations reported for leaf area loss may be related to the different methodologies used or to temporal alterations of some environmental conditions that in turn influence herbivory rates. More widespread and standardized sampling will be necessary in order to be able to detect herbivory patterns in these ecosystems. In the mangrove swamp examined in the present study during the period between May/91 and May/93, for example, a population boom of Hyblaea puera (Lepidoptera: Hyblaeidae) was detected that resulted in the widespread defoliation of Avicennia trees, and the death of many individuals. This same species of lepidopteron was responsible for the marked defoliation of Avicennia germinans (L.) Stearn in mangrove areas in Pará State (Menezes \& Mehlig 2005). Similar defoliations also caused by lepidopterons were observed affecting Avicennia marina (Forssk.) Vierh in Australia (West \& Thorogood 1985), Hong Kong (Anderson \& Lee 1995), and Singapore (Murphy 1990); affecting Avicennia alba Blume in Thailand (Piyakarnchana 1981); Excoecaria agallocha L. in Indonesia (Whitten \& Damanik 1986) and Singapore (Murphy 1990); and damaging Aegiceras corniculatum (L.) Blanco in Singapore (Murphy 1990).

The total loss of leaf area due to herbivory in the entire arboreal community in the present study was 8.8\% (table 2). Data available in the literature concerning damage caused by insects and arboreal crabs on living leaves among tree species in mangrove swamps demonstrate variations of from $1 \%$ to $47 \%$ of the total leaf area of a forest (Lacerda et al. 1986, Filomeno \& Castellani 1990, Farnsworth \& Ellison 1991, Feller 1995, Feller \& Mathis 1997, Erickson et al. 2004). Herbivory levels are generally quite low in the Caribbean (Onuf et al. 1977, Beever et al. 1979), while in the Indo-Pacific region these levels can be quite contrasting, varying from 2.1\% in Australia (Robertson \& Duke 1987) to $20 \%$ in the mangrove swamps of Papua, New Guinea (Johnstone 1981). 
Distribution of the different types of damage among the plant species examined - Galls were only observed on Avicennia (induced by Cecidomyia avicenniae [Diptera: Cecidomyiidae]) (figure 2). Galls have been reported in mangrove swamps in Brazil in Laguncularia racemosa (induced by Brachendus enodis [Acari, Eriophyidae]) (Santos-Mendonça \& Almeida-Cortez 2007), and in Avicennia germinans Learn. (induced by C. avicenniae) (Gonçalves-Alvim et al. 2001). In mangrove swamps in Belize, galls on the leaves of $A$. germinans were induced by unknown agents and were restricted only to that tree species (Farnsworth \& Ellison 1991).

Fungal spots were only seen on Laguncularia, and they were caused by Septoria sp. (which probably infested the plant following insect predation). Fungal infestations by Colletotrichum sp. and Ascochitia sp. were observed on Avicennia in necrotic areas that were formed by predation by hemipterons.

Leaf-margin damage was previously reported as being most expressive in Laguncularia and in Avicennia, and represented $82.2 \%$ and $56.3 \%$ of their total damaged leaf areas respectively. Both species demonstrated significantly more of this type of damage than was seen in Rhizophora $(P<0.05)$; this latter species demonstrated most damage due to necrosis (58.1\%) (figure 2). Leaf margin damage was most representative in Laguncularia in the mangrove swamps of Santa Catarina State (Filomeno \& Castellani 1990).

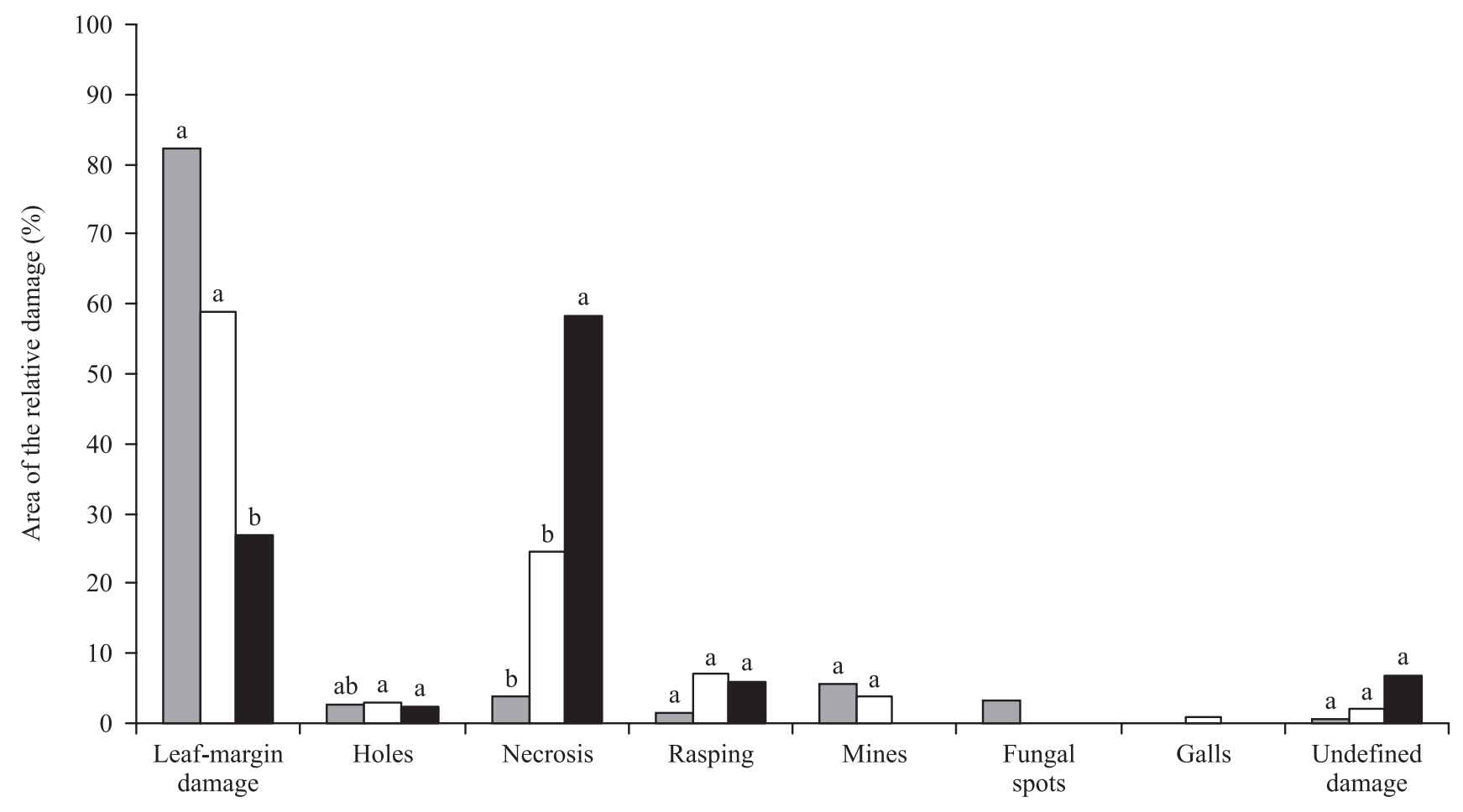

Types of damage

Figure 2. Representivity of the area of each type of leaf damage in relation to the total damaged area in Laguncularia racemosa ( $\square$ ), Avicennia schaueriana ( $\square$ ) and Rhizophora mangle ( $\square$ ) in a mangrove swamp at the mouth of the Piraquê River, Sepetiba Bay, Rio de Janeiro State, Brazil. Transformed data: arcsine of the $\sqrt{\%}$ of the relative area of the damage. Averages followed by the same letters do not differ significantly by the Tukey test at $5 \%$. The comparisons are valid among the species for each types of demage.

The percentage of leaf damage caused by "holes" was greatest in Avicennia; Laguncularia, however, showed significantly greater absolute numbers of leaves with holes than the other species $(P<0.05)$ (figure $3)$. This same type of damage was also reported for Laguncularia in mangrove swamps in Belize, and was caused by predation by hemipterons (Farnsworth \& Ellison 1991).

Rasping damage appeared greatest in Avicennia, although there were no statistically significant difference among the different species $(P>0.05)$. Leaf mines were observed in Avicennia and Laguncularia, and were most 


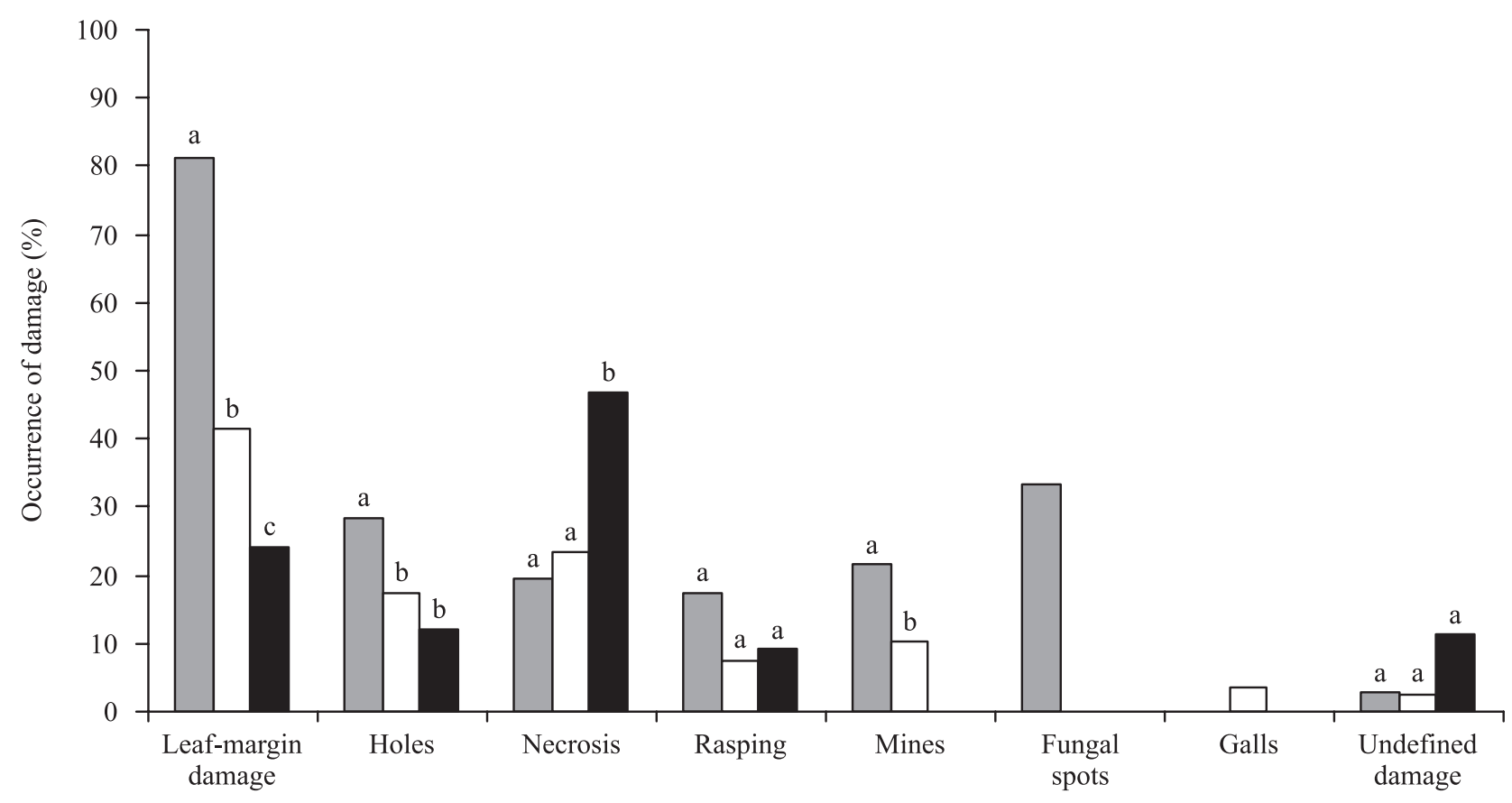

Types of damage

Figure 3. Percentage of the occurrences of each type of damage to Laguncularia racemosa ( $\square$ ), Avicennia schaueriana ( $\square$ ) and Rhizophora mangle ( $\mathbf{~ ) ~ i n ~ a ~ m a n g r o v e ~ s w a m p ~ a t ~ t h e ~ m o u t h ~ o f ~ t h e ~ P i r a q u e ̂ ~ R i v e r , ~ S e p e t i b a ~ B a y , ~ R i o ~ d e ~ J a n e i r o ~ S t a t e , ~ B r a z i l . ~}$ $(\mathrm{N}=600)$. Transformed data: arcsine of the $\sqrt{\%}$ of the relative area of the damage. Averages followed by the same letters do not differ significantly by the Tukey test at $5 \%$. The comparisons are valid among the species for each types of damage.

expressive in the former, although these differences were not statistically significant $(P>0.05)$. Both rasping and leaf-mining damage have been reported from mangrove swamps in Papua - New Guinea (Johnstone 1981) and Belize (Farnsworth \& Ellison 1991).

In general, the greatest levels of leaf damage among the three species studied were observed during the months of May to November (figure 4). Avicennia demonstrated greatest damaged in June and July, and less predation in April, while August and March represented the months with the greatest and least rates of damage respectively for Rhizophora, although these differences were not statistically significant $(P>0.05)$ in either of the two species. Laguncularia demonstrated the greatest total leaf damage in September and October and least damage during the month of February, with these differences being statistically significant $(P<0.05)$.

The differences observed in terms of leaf damage during the different months of the year in the study area were principally due to leaf fall and the subsequent production of new leaves during the rainy season (which occurs between the months of November and January) (Souza et al. 2000, Fernandes et al. 2005). As such, sampling the third pair of leaves included young leaves - and consequently leaves that were exposed to agents of damage for much less time.

Little variation was observed in terms of the relative damaged areas among the three species during the course of the study (figure 4). During March, August, September and October the relative damaged areas of Laguncularia differed significantly from Rhizophora. Avicennia differed from Laguncularia only during the month of September, but did not differ from Rhizophora during the course of the study $(P<0.05)$.

The damage types of galls and fungal spots (as well as their causative agents) were restricted to Laguncularia and Avicennia respectively in the mangrove area examined, and even the damage types common to all three species studied here demonstrated different intensities among the different taxa - indicating that some species were more susceptible to predator damage than others. Although damage caused by chewing insects (principally lepidopteron) represented almost all of the damage seen in Laguncularia, and more than half of that seen in Avicennia, chewing damage resulting in the death of leaf tissue was more significant in Rhizophora.

The levels of herbivory observed in the present study area can be considered low, even though comparisons 


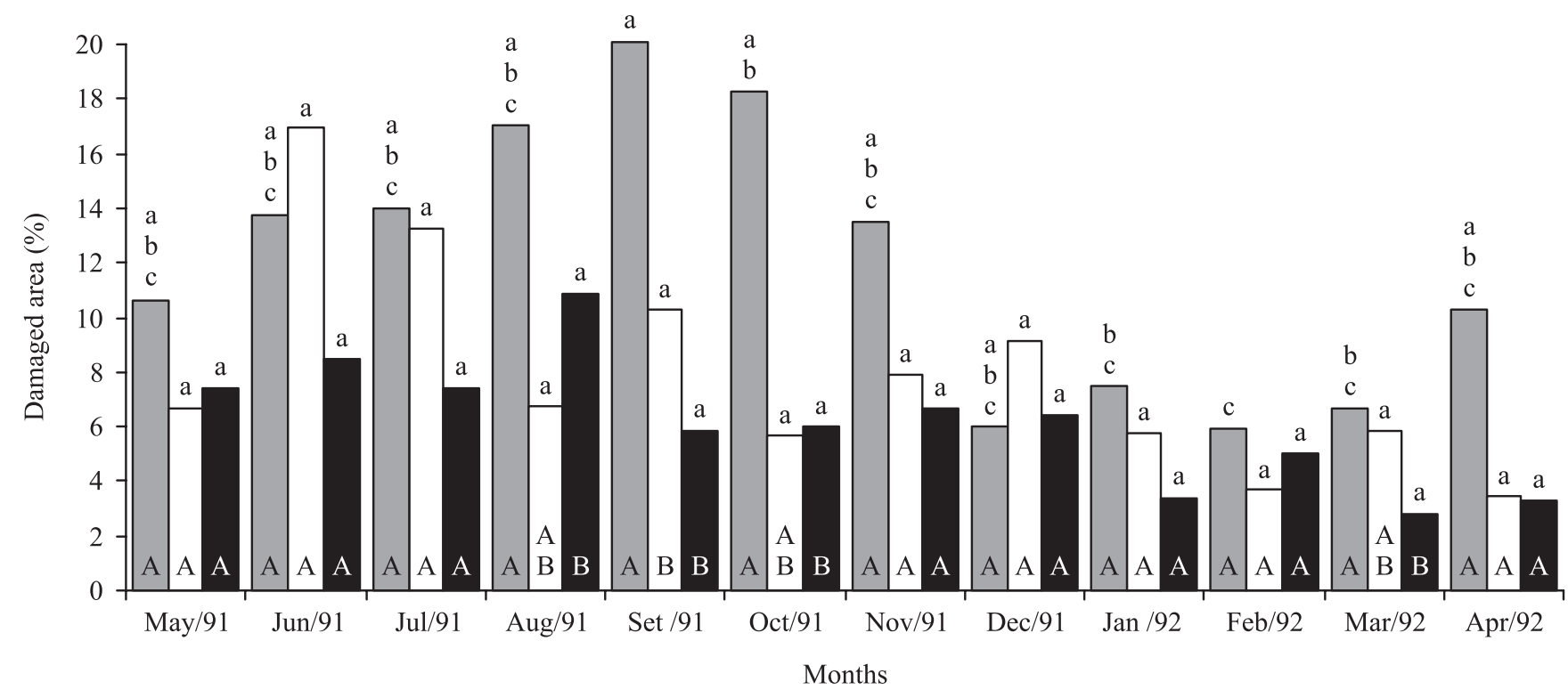

Figure 4. Monthly percentages of the damaged areas of Laguncularia racemosa ( $\square)$, Avicennia schaueriana ( $\square$ ) and Rhizophora mangle ( $\boldsymbol{\square})$ during each month of the year in a mangrove swamp at the mouth of the Piraquê River, Sepetiba Bay, Rio de Janeiro State, Brazil. Transformed data: arcsine of the $\sqrt{\%}$ of the relative area of the damage. Averages followed by the same letters do not differ significantly by the Tukey test at $5 \%$. Capital letters compare averages between the species for each month. Lower case letters compare the averages of each species between the months.

with other mangrove areas are still incipient, due to the lack of data from many regions and to the fact that reported differences in herbivory rates may only reflect different leaf-sampling methodologies. In order for these comparisons to be more robust, additional long-duration studies are needed that will accompany fluctuations in environmental conditions and herbivore insect populations.

Acknowledgements - The authors would like to thank Fabiano Mascarenhas P. Vicente for his help with the statistical analysis; Geraldo Wilson A. Fernandes and Frederico Falcão Salles for their critical suggestions concerning the manuscript; Heloisa Helena de Oliveira for her help with the fieldwork; as well as Luis S. Otero (in memorian) and Aldir de Oliveira Carvalho for their identifications of the entomological and phytopathological material respectively.

\section{References}

ANDERSON, C. \& LEE, Y. 1995. Defoliation of the mangrove Avicennia marina in Hong Kong: cause and consequences. Biotropica 27:218-226.

BASSET, Y. 1991. The spatial distribution of herbivory, mines and galls within an Australian rain forest tree. Biotropica 23:271-281.

BEERLING, D.J. \& FRY, J.C. 1990. A comparison of the accuracy, variability and speed of five different methods for estimating leaf area. Annals of Botany 65:483-488.
BEEVER, J.W., SIMBERLOFF, D. \& KING L.L. 1979. Herbivory and predation by the mangrove tree crab Aratus pisonii. Oecologia 4:317-28.

BOTO, V.G. \& BUNT, J.S. 1982. Carbon export from mangroves. In Cycling of carbon, nitrogen, sulfur and phosphorus in terrestrial and aquatic ecosystems (J.R. Freney \& I.E. Galbally, eds.). Springer-Verlag, Berlin, Heidelberg and New York, p.105-110.

COLEY, P.D. 1980. Effects of leaf age and plant life history patterns on herbivory. Nature 284:545-546.

COLEY, P.D. 1983. Herbivory and defensive characteristics of tree species in a lowland tropical forest. Ecology Monograph 53:209-233.

COLEY, P.D. \& AIDE, T.M. 1991. Comparisons of herbivory and plant defenses in temperate and tropical broadleaved forest. In Plant-animal interactions: evolutionary ecology in tropical and temperate regions. (P.W. Price, T.M. Lewinsohn, G.W. Fernandes \& W.W. Benson, eds.). Wiley, New York, p.25-48.

COLEY, P.D, BRYANT, J. \& CHAPIN, F. 1985. Resource availability and plant antiherbivore defense. Science 230:895-899.

D’CROZ, L. \& KWIECINSKI, Z.L. 1980. Contribuición de los manglares a las pesquerias de la Baía de Panamá. Revista de Biologia Tropical 28:13-29.

DIAS-BRITO, D. \& ZANINETTI, L. 1979. Étude géobotanique comparative de trois mangroves du littoral brésilien: Acupe (Bahia), Guaratiba (Rio de Janeiro) et Iguape (São Paulo). Notes du Laboratoire de Paleontologie de l’Université de Genève 4:57-65. 
DIRZO, R. 1987. Estudos sobre interacciones planta - herbivoro en "Los Tuxtlas",Veracruz. Revista de Biologia Tropical 35(supl. 1):119-131.

ELLISON, A.M. \& FARNSWORTH, E.J. 1996. Spatial and temporal variability in growth of Rhizophora mangle saplings on coral cays: links with variation in insolation, herbivory, and local sedimentation rate. Journal of Ecology 84:717-731.

ELSTER, C., PERDOMO, L., POLANÍA, J. \& SCHNETTER, M.L. 1999. Control of Avicennia germinans recruitment and survival by Junonia evarete larvae in a disturbed mangrove forest in Colombia. Journal of Tropical Ecology 15:791-805.

ERICKSON, A.A., BELL, S.S. \& DAWES, C.J. 2004. Does mangrove leaf chemistry help explain crab herbivory patterns? Biotropica 36:333-343.

ERNEST, K.A. 1989. Insect herbivory on a tropical understory tree: effects of leaf age and habitat. Biotropica 21:194199.

FARNSWORTH, E.J. \& ELLISON, A. 1991. Patterns of herbivory in Belizean mangrove swamps. Biotropica 23:555-567.

FARNSWORTH, E.J. \& ELLISON, A. 1997. Global patterns of pre-dispersal propagule predation in mangrove forests. Biotropica 29:318-330.

FEENY, P. 1976. Plant appearance and chemical defense. Recent Advances in Phytochemistry 10:1-40.

FELLER, I.C. 1995. Effects of nutrient enrichment on growth and herbivory in dwarf red mangrove (Rhizophora mangle L.) Ecology Monograph 65:477-505.

FELLER, I.C. \& MATHIS, W.N. 1997. Primary herbivory by wood-boring insects along an architectural gradient of Rhizophora mangle. Biotropica 29:440-451.

FERNANDES, G.W. 1994. Plant mechanical defenses against insect herbivory. Revista Brasileira de Entomologia 38:421-433.

FERNANDES, M.E.B., VIRGULINO, A.R.C., NASCIMENTO, A.A.M. \& RODRIGUES, L.F.P. 2005. Padrões de floraçao e frutificação em Laguncularia recemosa (L.) Gaertn. f.: uma avaliaçao metodológica. Boletim do Laboratório de Hidrobiologia 18:33-38.

FILOMENO, M.J.B. \& CASTELLANI, T.T. 1990. Estudo quantitativo e qualitativo dos leaf damage das plantas de um manguezal (Avicennia schaueriana Stapf \& Leechman, Laguncularia racemosa (L.) Gaertn e Rhizophora mangle (L.) da Ilha de Santa Catarina, SC. In Anais do II Simpósio de Ecossistemas da Costa Sul e Sudeste Brasileira, Estrutura, Função e Manejo (S. Watanabe, coord.), Aciesp, São Paulo, v.2, p.254-263.

FOX, L.R. \& MACAULEY, B.J. 1977. Insect grazing on Eucalyptus in response to variation in leaf tannins and nitrogen. Oecologia 29:145-62.

GANGE, A.C. \& BROWN, V.K. 1989. Insect herbivory affects size variability in plant populations. Oikos 56:351-356.
GONÇALVES-ALVIM, S.J., SANTOS, M.C.F.V. \& FERNANDES, G.W. 2001. Leaf gall abundance on Avicennia germinans (Avicenniaceae) along an interstitial salinity gradient. Biotropica 33:69-77.

HERNES, P.J., BENNER, R., COWIE, G.L., GONI, M.A., BERGAMASCHI, B.A. \& HEDGES, J.I. 2001. Tannin diagenesis in mangrove leaves from a tropical estuary: A novel molecular approach. Geochimica et Cosmochimica Acta 65:3109-3122.

HUFFAKER, C.B., DAHLSTEN, D.L., JANZEN, D.H. \& KENNEDY, G.G., 1984. Insect influences in the regulation of plant populations and communities. In Ecological entomology (C.B. Huffaker \& R.L. Rabb, eds.). John Wiley \& Sons, New York, p.659-691.

IUCN. 1983. Global status of mangrove ecosystems. International Union for Conservation of Nature and Natural Resources, Gland.

JOHNSTONE, I.M. 1981. Consumption of leaves by herbivores in mixed mangrove stands. Biotropica 13:252-259.

LACERDA, L.D., JOSÉ, D.N.V., REZENDE, C.E., FRANCISCO, M.C.F., WASSERMAN, J.C. \& MARTINS, J.C. 1986. Leaf chemical characteristics affecting herbivory in a new world mangrove forest. Biotropica 18:350-255.

LACERDA, L.D. \& REZENDE, C.E. 1990. Mangrove carbon export to the sea: a reevaluation of a paradigm. In Anais do II Simpósio de Ecossistemas da Costa Sul e Sudeste Brasileira, Estrutura, Função e Manejo (S. Watanabe, coord.), Aciesp, São Paulo, v.2, p.169-182.

LEE, S.Y. 1991. Herbivory as an ecological process in a Kandelia candel (Rhizophoraceae) mangal in Hong Kong. Journal of Tropical Ecology 7:337-348.

LUGO, A.E. \& SNEDAKER, S.C. 1974. The ecology of mangroves. Annual Review of Ecology and Systematics 5:39-64.

LOYOLA JR., R. \& FERNANDES, G.W. 1993. Herbivoria em Kielmeyra coriaceae (Guttiferae): efeitos da idade da planta, desenvolvimento e aspectos qualitativos de folhas. Revista Brasileira de Biologia 53:295-304.

LOWMAN, M.D. 1985. Temporal and spatial variability in insect grazing of the canopies of five Australian rainforest tree species. Australian Journal of Ecology 10:7-24.

LOWMAN, M.D. \& BOX, J.D. 1983. Variation in leaf toughness and phenolic content among five species of Australian rain forest trees. Australian Journal of Ecology 8:117-125.

MARQUIS, R.J. 1987. Variación en la herbivoría foliar y su importância selectiva en Piper arieianum (Piperaceae). Revista de Biologia Tropical 35(supl. 1):133-145.

MATTOS, C.L. 2005. Caracterização climática da Marambaia, RJ. In História Natural da Marambaia (L.F.T. Menezes, A.L. Peixoto \& D.S.D. Araujo, eds.). Edur, Seropédica, p.55-66. 
MCKEE, K. 1995. Mangrove species distribution and propagule predation in Belize: An exception to the dominance-predation hypothesis. Biotropica 27:334345.

MENEZES, M.P. \& MEHLIG, U. 2005. Desfolhação maciça de árvores de Avicennia germinans (L.) Stern 1958 (Avicenniaceae) por Hyblaea puera (Lepidóptera: Hyblaeidae), nos manguezais da Península de Bragança, Pará, Brasil. Boletim do Museu Paraense Emílio Goeldi, Série Ciências Naturais 1:221-226.

MURPHY, D.H. 1990. The natural history of insect herbivory on mangrove trees in and near Singapore. Raffles Bulletin of Zoology 38:119-203.

NASCIMENTO, M.T. \& HAY, J.D. 1993. Intraspecific variation in herbivory on Metrodorea pubescens (Rutaceae) in two forest types in central Brazil. Revista Brasileira de Biologia 53:143-152.

ODUM, W.E. \& HEALD, E.J. 1975. The detritus-based food web of an estuarine mangrove community. Pp. 265-286. In Estuarine Research. (L.E. Cronin, ed.). Academic Press, New York.

OFFENBERG, J., HAVANON, S., AKSORNKOAE, S., MACINTOSH, D.J. \& NIELSEN, M.G. 2004. Observations on the ecology of weaver ants (Oecophylla smaragdina Fabricius) in a Thai mangrove ecosystem and their effect on herbivory of Rhizophora mucronata Lam. Biotropica 36:344-351.

ONUF, C.P., TEAL, J.M. \& VALIELA, I. 1977. Interactions of nutrients plant growth and herbivory in a mangrove ecosystem. Ecology 58:514-526.

PIYAKARNCHANA, T. 1981. Severe defoliation of Avicennia alba Bl. by larvae of Cleora injectalia Walker. Journal Scientific Society of Thailand 7:33-36.

ROBERTSON, A.I., \& DUKE N.C. 1987. Insect herbivory on mangrove leaves in North Queensland. Australian Journal of Ecology 12:1-7.
RONCARATI, H. \& BARROCAS, S.L.S. 1978. Estudo preliminar dos sedimentos recentes superficiais da Baía de Sepetiba, Município do Rio de Janeiro - Itaguaí e Mangaratiba-RJ. Rio de Janeiro, Cenpes/ Petrobrás.

SAIFULLAH, S.M. \& MAHERA, S.A. 2004. Insect herbivory in polluted mangroves of the Indus Delta. Pakistan Journal of Botany 36:127-131.

SANTOS-MENDONÇA, I.V. \& ALMEIDA-CORTEZ, J.S. 2007. Caracterização da galha induzida por ácaro em Laguncularia racemosa (L.) Gaertn (Combretaceae). Biota Neotropica 7:163-170.

SOUZA, M.C., MELO, A.L., SILVA, A.N. \& MENEZES, L.F.T. 2000. Fitossociologia do manguezal do Canal do Bacalhau, Reserva Biológica e Arqueológica de Guaratiba, RJ. In Anais do V Simpósio de Ecossistemas Brasileiros: Conservação. Aciesp, São Paulo, v.2, p.389-396.

SCHOENER, T.W. 1988. Leaf damage in Island Buttonwood, Conocarpus erectus: correlations with pubescence, island area, isolation and the distribution of major carnivores. Oikos 53:253-266.

SKOV, M.W. \& HARTNOLL, R.G. 2002. Paradoxical selective feeding on a low-nutrient diet: why do mangrove crabs eat leaves? Oecologia 131:1-7.

STOWE, K.A. 1995. Intracrown distribution of herbivore damage on Laguncularia racemosa in a tidal influenced riparian habitat. Biotropica 27:509-512.

WEST, R.J. \& THOROGOOD, C.A. 1985. Mangrove dieback in Hunter River caused by caterpillars. Australian Fishing 44:27-28.

WHITTEN, A.J. \& DAMANIK, S.J. 1986. Mass defoliation of mangroves in Sumatra, Indonesia. Biotropica 18: 176.

ZAR, J.H. 1999. Biostatistical analysis. Prentice-Hall, New Jersey. 